JINOTEP Vol (6) No 1 (2019): 30-38

JINOTEP (Jurnal Inovasi Teknologi Pembelajaran):

Kajian dan Riset Dalam Teknologi Pembelajaran

http://journal2.um.ac.id/index.php/jinotep/index

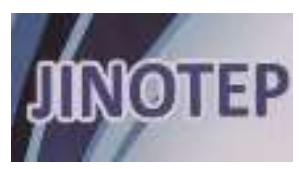

\title{
STRATEGI PEMBELAJARAN NILAI KARAKTER MANDIRI BERBANTUAN VIDEO ANIMASI UNTUK PAUD
}

Tenia Kurniawati, Punadji Setyosari, Dedi Kuswandi

Teknologi Pembelajaran,s Program Pascasarjana, Universitas Negeri Malang

\section{Article History}

Received: April 16, 2019

Accepted: May 9, 2019

Published:July 16, 2019

\section{Keywords}

Learning strategies, independent

characters, learning animation videos.

\begin{abstract}
Abstrak
Penelitian ini bertujuan untuk mengimplementasikan strategi pembelajaran dan mengembangkan media pembelajaran video animasi terintegrasi pada nilai karakter mandiri yang layak dan efektif pada PAUD untuk materi Tema Kebutuhanku, Sub Tema Kebersihan. Jenis penelitian yang digunakan peneliti adalah penelitan pengembangan dengan menggunakan model ADHIE. Subjek pada penelitian ini adalah 20 anak kelompok TK B pada PAUD Permata Tambrauw. Data dianalisis menggunakan metode kualitatif dan kuantitatif. Setelah divalidasi oleh ahli media dan ahli materi, media video animasi pembelajaran mendapat penilaian dengan kategori sangat layak. Hasil uji coba kelompok kecil berjumlah 5 anak mendapat hasil sangat layak. Hasil uji lapangan (uji kelompok besar) berjumlah 20 anak mendapat hasil sangat layak. Jadi strategi cooperative learning dan media video animasi adalah sangat layak dan efektif digunakan dalam pembelajaran.
\end{abstract}

\begin{abstract}
This study aims to implement learning strategies and develop integrated animation video learning media on the value of a proper and effective independent character in PAUD for the theme of My Needs, Sub-Hygiene Themes. The type of research used by researchers is development research using the ADHIE model. The subjects in this study were 20 kindergarten children B in the PAUD Permata Tambrauw. Data were analyzed using qualitative and quantitative methods. After being validated by media experts and material experts, the learning animation video media was rated as very feasible. The results of a small group trial of 5 children received very decent results. The results of field tests (large group test) totaling 20 children received very decent results. So the cooperative learning strategy and video animation media are very feasible and effective to use in learning
\end{abstract}

Corresponding author :

Adress: Jl. Terusan Wijaya Kusuma Kav. 6 No 36. Lowokwaru, Malang Jawa Timur Indonesia Instansi: Universitas Negeri Malang

E-mail: tenia.kurniaassem@gmail.com
2019 Universitas Negeri Malang p-ISSN 2406-8780 e-ISSN 2654-7953 


\section{PENDAHULUAN}

Pentingnya pendidikan karakter adalah solusi untuk mengatasi degradasi moral bangsa yang makin terpuruk, pemerintah melalui menjelaskan bahwa pendidikan karakter harus diberikan kepada tiap siswa dalam tiap jenjang pendidikan melalui kurikulum pembelajaran. Pendidikan karakter yang wajib diberikan kepada siswa adalah nilai karakter: Religius, Jujur, Toleransi, Disiplin, Kerja Keras, Kreatif, Mandiri, Demokratis, Rasa Ingin Tahu, Semangat Kebangsaan, Cinta Tanah Air, menghargai Prestasi, Bersahabat/Komunikatif, Cinta Damai, Gemar Membaca, Peduli Lingkungan, Peduli Sosial, dan Tanggung Jawab (Kemendiknas, 2010:9). Salah satu pendidikan karakter yang harus di tanamkan sejak dini pada anak usia dini adalah pendidikan karakter mandiri, karakter mandiri adalah keadaan yang dapat berdiri sendiri atau tidak tergantung kepada orang lain tetapi masih mau mendengarkan masukan orang lain. Namun, kenyataan yang terjadi karakter mandiri anak kurang dan ditandai dengan anak-anak masih banyak yang bergantung kepada orang lain. Hal ini tentu saja tidak boleh dibiarkan, anak-anak harus diberi teladan dan pembiasaan untuk memiliki karakter mandiri agar terbiasa dan terlatih hingga mereka dewasa. Jika anak sejak usia dini sudah memiliki karakter mandiri sejak dini maka saat mereka besar bisa bertumbuh menjadi manusia yang inovatif, kreativ serta berguna bagi masyarakat banyak. Oleh sebab itu pembelajaran karakter harus ditanamkan sejak dini melalui pembelajaran di rumah maupun di sekolah.

Pembelajaran karakter yang bisa diberikan pada anak salah satunya adalah di sekolah melalui kurikulum Tema yang dikembangkan sendiri oleh guru di sekolah. Gagne dan Briggs (1979:172) menyatakan bahwa guru sebagai tim dalam menyusun pembelajaran harus tepat memilih metode, desain ataupun strategi pembelajaran, salah satunya ditunjang dengan media yang tepat untuk mencapai tujuan yang telah ditentukan.

Pemelihan metode dan strategi harus tepat sesuai dengan karakteristik anak usia dini agar pembelajaran lebih efisien, selain itu pemilihan media pembelajaran juga harus diperhatikan agar menarik minta anak usia dini dalam pembelajaran karakter mandiri. Kemp \&
Dayton (1985:3) menjelaskan, "Instructional media also make use of the power of pictures, words, and sounds to compel attention, to help an audience understand ideas and acquire information too complex for verbal explanation alone, and to help overcome the limitations of time, size and space". Hal ini menjelaskan bahwa media pembelajaran yang menggunakan unsur gambar, tulisan dan suara dapat meningkatkan perhatian, membawa anak usia dini memahami ide dan mendapatkan informasi yang sangat kompleks dan membutuhkan penjelasan tersendiri, serta dapat mengatasi keterbatasan waktu, ukuran dan tempat. Dengan demikian, dibutuhkan media yang tepat dan sangat sesuai untuk anak usia dini terkait dengan pembelajaran karakter mandiri terutama pada Tema kebutuhanku, Sub Tema Kebersihan yang akan menjadi focus penelitian ini.

Media itu diharapkan dapat mempermudah anak usia dini dalam belajar pendidikan karakter madiri yang terintegrasi pada kurikulum Tema, yaitu tema kebutuhanku sub tema kebersihan.

Berdasarkan hasil need analysis yang dilakukan pada Bulan Agustus 2018 di kelompok TK B PAUD Permata Tambrauw melalui kegiatan wawancara, observasi, kajian literatur, serta analisis media pembelajaran yang sudah ada maka diperoleh beberapa permasalahan, dimana guru kurang inovativ dalam mengembangkan strategi pembelajaran pendidikan karakter yang tepat buat anak usia dini, sehingga banyak anak usia dini di lembaga tersebut yang belum memiliki sikap karakter mandiri yang baik untuk tingkatan anak PAUD. Selain itu ditemukan beberapa permasalahan terkait media pembelajaran, media yang digunakan masih kurang fariativ hanya sebatas buku gambar, papan tulis, buku cerita jenis print teks. Media yang terintegrasi dengan pendidikan karakter mandiri belum ada, serta berbasis kearifan lokal juga belum ditemukan.

Pada aktivitas pembelajaran di kelas ditemukan fakta bahwa banyak anak yang membuang sampah di sembarang tempat, tidak mencuci tangan sebelum makan. Selain itu banyak juga anak usia dini di tempat itu yang tidak mandi saat menuju ke lembaga tersebut. Hal ini tentu saja menjadi sebuah masalah besar, karena jika kebiasaan tersebut dibiarkaan maka akan menjadi gaya hidup hingga mereka besar kelak. Selain itu dampak jika tidak hidup bersih 
juga sangat berbahaya bagi tumbuh kembang anak. Selain kurangnya sikap menjaga kebersihan diri, banyak anak yang masih belum mandiri dalam pembelajaran di kelas, mereka masih banyak yang bergantung kepada guru dalam menyelesaikan tugas dalam pembelajaran di kelas. Sikap tergantung pada guru dan teman dalam penyelesaian tugas juga tidak dibenarkan, mengingat mereka sudah masuk kelompok TK B yang akan melanjutkan pada jenjang sekolah dasar dimana sudah dituntut untuk lebih mandiri lagi.

Berbagai permasalahan di atas terjadi karena dalam proses pembelajaran pendidikan karakter, guru salah dalam menggunakan strategi dan metode yang tepat. Selain itu penggunaan media yang kurang menarik juga menjadi faktor utama tidak efiktivnya pembelajaran pendidikan karakter terutama pada Tema Kebutuhanku, sub tema kebersihan. Guru masih menggunakan metode konvensional yang hanya menyampaikan materi mengacu pada buku teks dan paket LKS PAUD yang bukan buatan guru. Dengan demikian, guru masih banyak menerangkan dengan metode ceramah yang lebih menekankan pada ketuntasan materi dan mengabaikan nilai-nilai karakter yang dapat diintegrasikan dalam materi pelajaran. Hal ini menyebabkan anak usia dini banyak yang merasa bosan sehingga menyebabkan rendahnya motivasi anak usia dini untuk meneladani pendidikan karakter mandiri.

Permasalahan yang terjadi di PAUD Permata Tambrauw khususnya di kelompok TK B tersebut harus segera diatasi. Dibutuhkan strategi dan media pembelajaran yang tepat untuk pembelajaran pendidikan karakter agar bisa menarik perhatian anak. Salah satu strategi yang tepat dalam pembelajaran pendidikan karakter adalah dengan menggunakan strategi cooperativ learning. David \& Johnson (1999) mendefinisikan cooperativ learning adalah sebagai strategi pembelajaran dalam bentuk kelompok kecil dimana setiap peserta didik memiliki tingkat kemampuan berbeda, dengan menggunakan berbagai macam aktifitas belajar untuk meningkatkan pemahaman terhadap materi. Tujuan dari strategi pembelajaran ini adalah anak dilatih untuk bekerjasama menyelesaikan tugas bersama-sama dengan kelompoknya selain itu juga bertanggung secara pribadi terhadap tugas yang sudah dibagi oleh ketua kelompok (sagala, 2002: 177). Dengan penerapan strategi ini dalam pembelajaran, maka secara tidak langsung guru sudah menerapkan beberapa nilai karakter salah satunya adalah karakter mandiri. Anak tidak akan bergantung pada guru, tetapi kerja sama dengan teman dalam menyelesaikan tugas selain itu anak juga dilatih mandiri saat kelompok kecil mereka membagi-bagi tugas untuk tiap anggotanya.

Selain strategi, media pembelajaran juga harus dipilih dan disesuaikan dengan karakeristik anak usia dini. Media yang menarik dan lebih dekat dengan dunia anak saat ini adalah video animasi. Penelitian Kayaoglu, Akbas, dan Ozturk (2011) menjelaskan bahwa penggunaan animasi dalam pembelajaran kosakata menunjukkan ada dampak positif. Animasi berguna karena lebih mengoptimalkan indera daripada yang bersifat tekstual. Penelitian ini mendukung gagasan bahwa penggunaan animasi dapat diintegrasikan ke dalam kelas bukan sebagai cara alternatif, tetapi sebagai cara tambahan untuk memberikan kontribusi positif pada suasana kelas dan motivasi anak animasi menurut Ivers \& Barron (2010:98) menjelaskan bahwa animasi merupakan gambar dengan meniru pergerakan. Semua animasi terdiri dari serangkaian gambar (dengan sedikit perubahan dari satu ke yang berikutnya) yang ditampilkan dalam waktu yang cepat dan menipu mata dengan melihatnya sebagai gerakan. Dengan demikian, pesan-pesan pembelajaran disampaikan secara audio visual dengan disertai unsur gerak sehingga lebih hidup. Video animasi yang digunakan dalam penelitian ini diharapkan dapat membantu guru menghadirkan suatu rekaman perjuangan tokoh-tokoh pahlawan pada masa lalu dengan unsur gambar, suara, suasana, ruang, dan waktu. Gambar dengan gerak sederhana juga menjadikan jalan cerita yang dialami tokoh-tokoh di dalamnya lebih menarik. Anak akan lebih memerhatikan gambar yang bergerak daripada yang tidak bergerak. Dengan demikian, gambar yang bergerak disertai dengan suara yang sesuai dengan latar yang menarik diharapkan dapat meningkatkan perhatian anak untuk memahami isi video animasi. Perhatian dan ketertarikan pada pembelajaran melalui video animasi itulah yang mengindikasikan motivasi belajar anak meningkat. Astuti \& Mustadi (2014:258) menjelaskan bahwa anak akan memiliki motivasi lebih baik bila pembelajaran menggunakan media animasi. Dengan demikian, guru yang telah 
menggunakan media pembelajaran telah berhasil memberikan motivasi ekstrinsik pada anak.

Penggunaan media video animasi diharapkan dapat meningkatkan perhatian anak dalam pembelajaran pendidikan karakter untuk materi Tema kebutuhanku, sub tema kebersihan sehingga diharapkan mampu menjadi modia yang tepat dalam memberikan keteladanan kepada anak usia dini.

Penanaman nilai karakter mandiri dalam aktivitas sehari-hari maupun dalam proses pembelajaran merupakan hal-hal kecil yang harus diajarkan dan ditanamkan sejak dini kepada anak-anak. Hal ini sesuai dengan penelitian Smithikrai, Longthong, dan Peijsel (2015) bahwa pengaruh penggunaan film untuk meningkatkan sikap mandiri dan tanggung jawab pribadi anak. Anak yang belajar dengan menggunakan film mengalami peningkatan yang signifikan pada kemandirian dan tanggung jawab pribadinya. Melalui film animasi, anak cenderung dipengaruhi oleh perilaku yang digambarkan dalam film. Berdasarkan latar belakang di atas, dapat disimpulkan bahwa guru perlu menerapkan strategi pembelajaran cooperativ learning dan membutuhkan media video animasi yang digunakan untuk meningkatkan motivasi dalam meneladani nilai karakter mandiri. Strategi cooperativ learning dan media video animasi dalam pembelajaran pendidikan karakter dalam materi Tema Kebutuhanku, Sub Tema Kebersihan belum pernah diimplementasikan serta dikembangkan pada PAUD Permata Tambrauw sehingga akan sangat berguna sebagai strategi dan media pembelajaran alternatif dalam proses pembelajaran.

\section{METODE}

Penelitian merupakan penelitian dan pengembangan (Research and Development) video animasi pembelajaran terintegrasi nilai karakter mandiri untuk PAUD. Pengembangan yang diterapkan menggunakan model ADDIE. Model ini terdiri dari lima tahap pengembangan yaitu Analysis, Design, Development, Implementation, and Evaluations. Alasan pemilihan Model ADDIE karena model ini sistematis dan sederhana, selain itu evaluasi bisa dilakukan pada setiap tahapan, sehingga akan berpengaruh terhadap tahapan selanjutnya. Penelitian ini menggunakan pendekatan kualitatif dan kuantitatif. Uji coba produk terdiri dari tiga tahap, yaitu uji coba kelompok kecil, uji coba kelompok besar (lapangan). Sebelum uji coba, produk perangkat pembelajaran divalidasi oleh ahli materi dan ahli pembelajaran. Subjek uji coba dalam penelitian ini adalah anak usia dini PAUD Permata Tambrauw kelompok TK B. Subjek uji coba kelompok kecil 5 anak dan subjek uji coba kelompok besar 20 anak. Instrumen pengumpulan data yang digunakan dalam penelitian ini yaitu skala penilaian produk oleh ahli materi dan ahli media, dan angket respons untuk guru dan anak usia dini. Data penelitian berupa hasil wawancara, observasi, studi pustaka, dan analisis perangkat pembelajaran yang digunakan oleh guru sebagai analisis kebutuhan (need analysis) pengembangan perangkat pembelajaran. Data tersebut dianalisis menggunakan teknik analisis deskriptif kuantitat untuk mendapatkan perangkat pembelajaran yang layak dan efektif. Analisis kelayakan media video animasi didapatkan dari tabulasi semua data dari respons siswa, respons guru, serta penilaian dari validator ahli materi dan ahli media. Kualitas media video animasi berdasarkan hasil pengembangan yang sudah dilakukan dan diperoleh skornya, kemudian data berupa angkaangka tersebut diubah menjadi data kualitatif dengan skala lima. Acuan pengubahan skor menjadi skala 5 menurut akbar (2013)

\section{HASIL}

Pada saat proses pembelajaran, peneliti menggunakan strategi cooperativ learning (pembelajaran berkelompok) dikondisikan belajar secara berkelompok agar anak bisa bekerjasama dengan temannya dalam menyelesaikan tugas dari guru kelas. Terlihat anak mulai antusias dalam mengikuti pembelajaran dan memperhatikan tugas-tugas yang diberikan, serta bersemangat dalam mengerjakan tugas. Setelah peneliti mengembangkan produk video animasi pembelajaran yang terintegrasi karakter mandiri, maka diperoleh hasil dari tim ahli tujuannya adalah untuk menguji kelayakan dan validitas sebelum dipergunakan dalam pembelajaran di kelas PAUD.

Data Hasil Validasi Ahli

Tabel 1 Hasil Validasi Materi 
34 JINOTEP (Jurnal Inovasi dan Teknologi Pembelajaran): Kajian dan Riset dalam Teknologi Pembelajaran Vol. 6, No. 1, Oktober 2019, Hal 30-38

\begin{tabular}{llll}
\hline No & $\begin{array}{l}\text { Aspek Yang } \\
\text { Dinilai }\end{array}$ & $\begin{array}{l}\text { Persentase } \\
\text { rata-rata }\end{array}$ & Keterangan \\
\hline 1 & $\begin{array}{l}\text { Aspek } \\
\text { Pendidikan }\end{array}$ & $94 \%$ & Sangat Valid \\
\hline 2 & $\begin{array}{l}\text { Aspek } \\
\text { Ketepatan } \\
\text { Materi }\end{array}$ & $95 \%$ & Sangat Valid \\
& & \\
\hline $\begin{array}{l}\text { Rata-rata } \\
\text { keseluruhan }\end{array}$ & $94 \%$ & Sangat Valid \\
\hline
\end{tabular}

Penyajian Data Ahli Media

Tabel 2 Data Instrumen Uji Coba Ahli Media

\begin{tabular}{llll}
\hline No & $\begin{array}{l}\text { Aspek Yang } \\
\text { Dinilai }\end{array}$ & $\begin{array}{l}\text { Presentase } \\
\text { rata-rata }\end{array}$ & Keterangan \\
\hline 1 & $\begin{array}{l}\text { Aspek } \\
\text { Multimedia }\end{array}$ & $92 \%$ & Sangat valid \\
\hline 2 & $\begin{array}{l}\text { Aspek } \\
\text { Tampilan } \\
\text { Program }\end{array}$ & $95 \%$ & Sangat valid \\
\hline 3 & $\begin{array}{l}\text { Kualitas } \\
\text { Teknis }\end{array}$ & $94 \%$ & Sangat valid \\
\hline $\begin{array}{l}\text { Rata - rata } \\
\text { keseluruhan }\end{array}$ & $94 \%$ & Sangat valid \\
\hline
\end{tabular}

\section{Penyajian Data Praktisi}

Uji coba praktisi dilakukan oleh satu guru kelas kelompok TK B Paud Permata Tambrauw dengan menggunakan angket validasi praktisi. Hasil uji coba praktisi dapat dilihat dari tabel berikut:

Tabel 3 Hasil validasi uji coba Praktisi (Guru

\begin{tabular}{llll} 
& \multicolumn{3}{c}{ PAUD) } \\
\hline No & $\begin{array}{l}\text { Aspek yang } \\
\text { dinilai }\end{array}$ & $\begin{array}{l}\text { Persentase } \\
\text { rata-rata }\end{array}$ & Keterangan \\
\hline 1 & $\begin{array}{l}\text { Aspek } \\
\text { pendidikan }\end{array}$ & $92 \%$ & Sangat valid \\
\hline 2 & $\begin{array}{l}\text { Aspek } \\
\text { ketepatan } \\
\text { materi }\end{array}$ & $94 \%$ & Sangat valid \\
\hline 3 & $\begin{array}{l}\text { Aspek } \\
\text { kemenarikan }\end{array}$ & $96 \%$ & Sangat valid \\
\hline 4 & $\begin{array}{l}\text { Aspek } \\
\text { kepraktisan }\end{array}$ & $93 \%$ & Sangat valid \\
\hline $\begin{array}{l}\text { Rata-rata } \\
\text { keseluruhan }\end{array}$ & $95 \%$ & \\
\hline
\end{tabular}

Penyajian Data Audience PAUD

A. Uji Coba Kelompok Kecil

Uji coba kelompok kecil ini bertujuan untuk mengetahui kekurangan-kekurangan pada produk video pembelajaran yang telah dibuat dan meninjau kembali atau perbaikan yang telah dilakukan oleh pengembang. Uji coba ini dilakukan oleh 5 anak yang berada di kelompok TK B PAUD Permata Tambrauw. Setelah di lakukan uji coba kelompok kecil, maka ditentukan hasil berupa data dari angket penilaian dan tanggapan anak pada kelompok TK B terhadap produk pengembangan video pembelajaran terintegrasi karakter mandiri. Hasil tersebut disajikan dalam tabel berikut:

Tabel 4 Data Hasil Uji Coba Kelompok Kecil

\begin{tabular}{llll}
\hline No & $\begin{array}{l}\text { Aspek yang } \\
\text { dinilai }\end{array}$ & $\begin{array}{l}\text { Persentase } \\
\text { rata-rata }\end{array}$ & Keterangan \\
\hline 1 & $\begin{array}{l}\text { Aspek } \\
\text { kemenarikan }\end{array}$ & $96 \%$ & Sangat valid \\
\hline 2 & $\begin{array}{l}\text { Aspek } \\
\text { Kepraktisan }\end{array}$ & $94 \%$ & Sangat valid \\
\hline $\begin{array}{l}\text { Rata-rata } \\
\text { Keseluruhan }\end{array}$ & $95 \%$ & Sangat valid \\
\hline
\end{tabular}

B. Uji Coba Kelompok Besar (Lapangan)

Uji coba lapangan ini bertujuan untuk mengetahui sejauh mana media video animasi pembelajaran yang dikembangkan dan telah direvisi ini dapat memenuhi kriteria yang diharapkan dan layak digunakan dalam proses pembelajaran di PAUD khususnya anak TK B. Uji coba lapangan ini dilakukan oleh 20 orang anak pada kelompok TK B PAUD Permata Tambrauw. Hasil tersebut disajikan dalam tabel berikut:

Tabel 5 data hasil uji coba lapangan

\begin{tabular}{|c|c|c|c|}
\hline No & $\begin{array}{l}\text { Aspek yang } \\
\text { dinilai }\end{array}$ & $\begin{array}{l}\text { Persentase } \\
\text { rata-rata }\end{array}$ & Keterangan \\
\hline 1 & $\begin{array}{l}\text { Aspek } \\
\text { Kemenarikan }\end{array}$ & $94 \%$ & Sangat valid \\
\hline 2 & $\begin{array}{l}\text { Aspek } \\
\text { Kepraktisan }\end{array}$ & $94 \%$ & Sangat valid \\
\hline $\begin{array}{l}\text { Rata } \\
\text { kese }\end{array}$ & $\begin{array}{c}- \\
\text { ruhan }\end{array}$ & $94 \%$ & Sangat valid \\
\hline
\end{tabular}

\section{Analisis Data Uji Coba}

Analisis Data Uji Coba Ahli Materi

Sesuai dengan paparan tabel 1 tentang hasil validasi materi, beberapa aspek yang dikategorikan sangat valid dan cukup valid disajikan pada tabel 6 berikut ini.

Tabel 6 Analisis Validasi Materi

\begin{tabular}{|c|c|}
\hline Sangat Valid & $\mathrm{Cuk}$ \\
\hline Aspel & मUKद \\
\hline $\begin{array}{ll}\text { - Materi sesuai KD } \\
\text { Kurikulum } 2013\end{array}$ & $\begin{array}{l}\text { - Materi } \\
\text { dengan }\end{array}$ \\
\hline
\end{tabular}




\begin{tabular}{|c|c|}
\hline $\begin{array}{l}\text { tema "Kebutuhanku, } \\
\text { sub tema } \\
\text { kebersihan" } \\
\text { - Susunan materi } \\
\text { sesuai dengan tujuan } \\
\text { pembelajaran } \\
\text { - Sesuai tingkat } \\
\text { perkembangan anak } \\
\text { usia dini } \\
\text { - Materi mudah } \\
\text { dipahami anak usia } \\
\text { dini } \\
\text { Tersusun secara } \\
\text { sistematis } \\
\text { - Contoh jelas dan } \\
\text { mendukung } \\
\text { pemahaman anak } \\
\text { usia dini } \\
\text { - Materi merangsang } \\
\text { keingintahuan anak } \\
\text { usia dini } \\
\text { Aspek Ketepatan Materi } \\
\text { - Tujuan } \\
\text { pembelajaran jelas } \\
\text { dan mudah } \\
\text { dipahami } \\
\text { - Penyajian animasi } \\
\text { - Pesuai materi } \\
\text { memyajian video } \\
\text { menyajian audio } \\
\text { Penggunaan bahasa } \\
\text { mendukung } \\
\text { kemudahan } \\
\text { memahami materi }\end{array}$ & $\begin{array}{l}\text { Aspek Ketepatan } \\
\text { Materi } \\
\text { - Kedalaman tujuan } \\
\text { pembelajaran } \\
\text { sesuai }\end{array}$ \\
\hline
\end{tabular}

\section{Analisis Data Uji Coba Ahli Media}

Sesuai paparan tabel 2 tentang hasil validasi tampilan media, beberapa aspek yang dikategorikan sangat valid dan cukup valid disajikan pada tabel 7 berikut ini.

Tabel 7 Analisis validasi tampilan media

\begin{tabular}{|c|c|}
\hline Sangat Valid & Cukup Valid \\
\hline $\begin{array}{ll}\text { Aspek Multimedia } \\
\text { - } & \text { Kemudahan } \\
\text { pengelolaan } \\
\text { program } \\
\text { - Kemudahan } \\
\text { pengoperasian } \\
\text { program }\end{array}$ & $\begin{array}{l}\text { Aspek Multimedia } \\
\text { - Pemanfaatan } \\
\text { multimedia untuk } \\
\text { mengembangkan } \\
\text { pembelajaran lain } \\
\text { - } \\
\text { Penggunaan } \\
\text { multimedia untuk } \\
\text { pembelajaran di } \\
\text { rumah oleh anak } \\
\text { usia dini }\end{array}$ \\
\hline $\begin{array}{l}\text { Aspek Tampilan } \\
\text { Program }\end{array}$ & $\begin{array}{l}\text { Aspek Tampilan } \\
\text { Program }\end{array}$ \\
\hline
\end{tabular}

- Sesuai karakter anak usia dini

- Tampilan tokoh sesuai kaarakter

- Animasi memperjelas materi

- Media menarik dan sesuai tema

- Musik pengiring sesuai

- Pengisi suara sesuai

- Kemampuan multimedia menarik perhatian anak usia dini

- Kemampuan multimedia sebagai alat bantu memahami materi

\begin{tabular}{|c|c|}
\hline $\begin{array}{l}\text { Kualitas teknis } \\
\text { - } \quad \text { Menciptakan rasa } \\
\text { senang anak usia } \\
\text { dini } \\
\text { - } \quad \text { Bahasa interaktif } \\
\text { - } \text { Originalitas } \\
\text { multimedia } \\
\text { - } \quad \text { Tersaji secara } \\
\text { sistematis }\end{array}$ & $\begin{array}{l}\text { Kualitas Teknis } \\
\text { - } \quad \text { Suara jelas } \\
\text { - } \quad \text { Musik pengiring } \\
\quad \text { jelas }\end{array}$ \\
\hline
\end{tabular}

\section{Analisis Data Uji Coba Praktisi}

Sesuai dengan paparan tabel 3 tentang validasi praktisi, beberapa aspek yang dikategorikan sangat valid dan cukup valid disajikan dalam tabel 8 .

Tabel 8 Analisis Validasi Praktisi

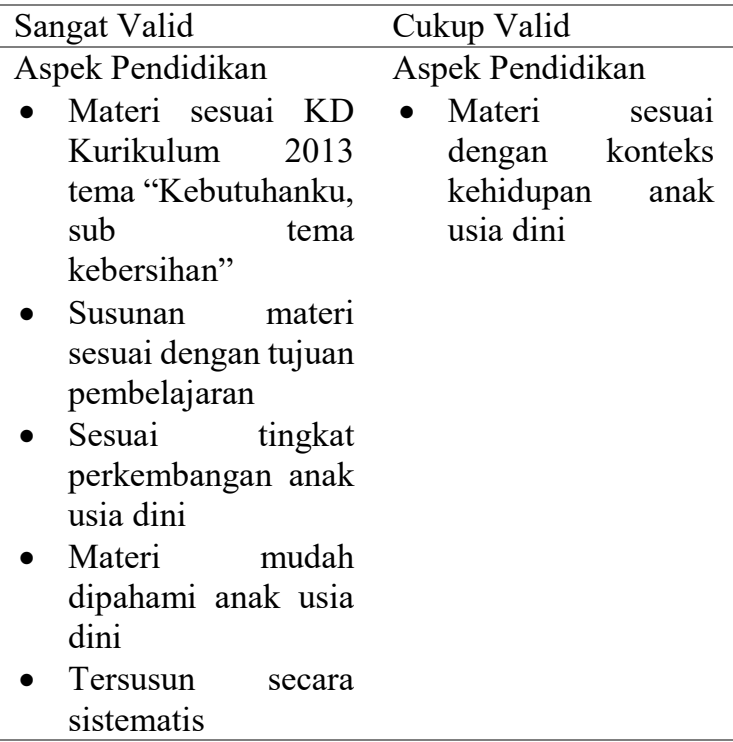


36 JINOTEP (Jurnal Inovasi dan Teknologi Pembelajaran): Kajian dan Riset dalam Teknologi Pembelajaran Vol. 6, No. 1, Oktober 2019, Hal 30-38

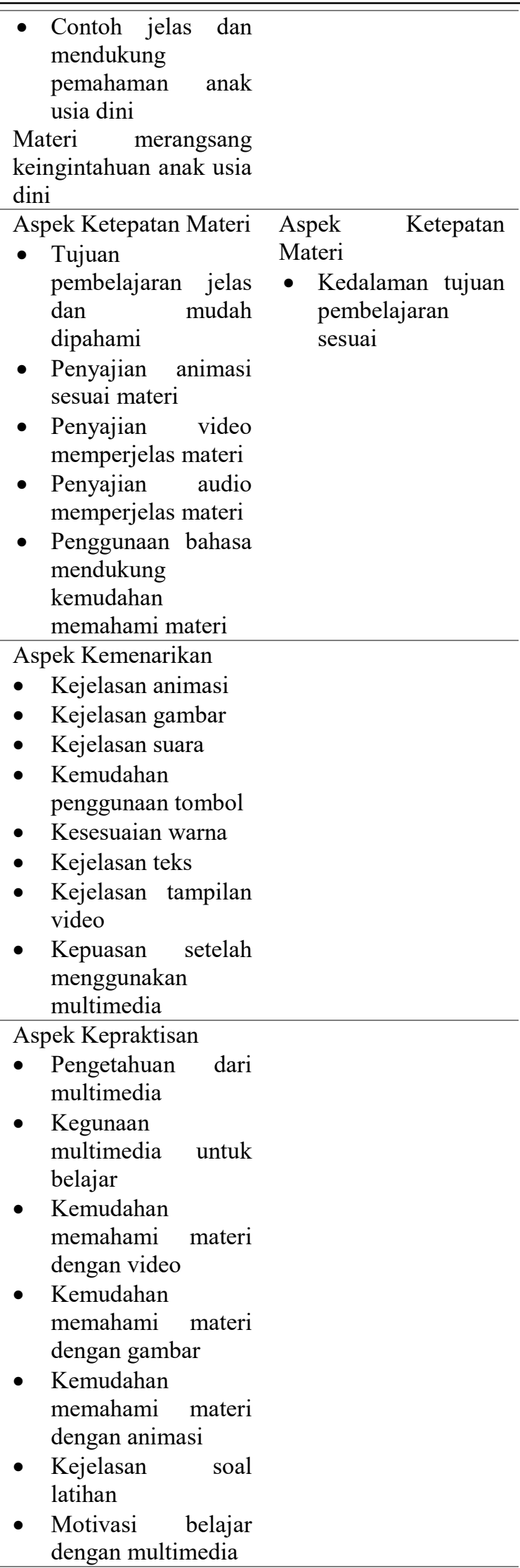

Analisis Hasil Uji Lapangan

Uji coba kelompok kecil dilakukan oleh 5 anak PAUD kelompok TK B, mereka diarahkan untuk menggunakan video pembelajaran ini secara utuh atau dari awal hingga akhir. Tabel 4 diperoleh hasil presentase yaitu $96 \%$, sehingga video animasi pembelajaran layak digunakan dalam pembelajaran.

Uji coba lapangan atau uji coba kelompok besar dilakukan kepada 20 anak PAUD Permata Tambrauw pada kelompok TK B. Uji coba dilakukan selama satu minggu di distrik Sausapor Kabupaten Tambrauw dengan menggunakan strategi cooperative learning dan menggunakan video animasi pembelajaran yang terintegrasi karakter mandiri. Berdasarkan hasil analisis dari data uji coba lapangan yang ada pada tabel 6 diperoleh hasil rata-rata presentase 94, maka video animasi pembelajaran layak tersebut digunakan dalam pembelajaran nilai karakter mandiri pada Tema kebutuhanku, sub tema kebersihan.

\section{Analisis Hasil Belajar}

Penilaian pada PAUD dilaksanakan pada saat anak-anak melaksanakan aktivitas bermain dan belajar dengan teman-teman serta guru. Penilaiannya bisa dilihat saat anak-anak mengomunikasikan pikiran melalui hasil karyanya, berdiskusi dengan teman kelompoknya, dan tindakan yang sudah dilakukan anak di kelas. Dalam melakukan penilaian terhadap anak digunakan skala capaian atau skala penilaian.

Tabel 9 Pedoman Observasi Sikap Mandiri

\begin{tabular}{cl}
\hline NO & Indikator Penilaian \\
\hline 1 & $\begin{array}{l}\text { Terbiasa mencuci } \\
\text { tangan dan menggosok gigi sendiri }\end{array}$ \\
\hline 2 & Bisa memakai pakaian sendiri \\
\hline 3 & Terbiasa membuang sampah pada tempatnya \\
\hline 4 & $\begin{array}{l}\text { Anak berusaha menyelesaikan permasalahannya } \\
\text { sendiri di dalam kelas }\end{array}$ \\
\hline 3 & $\begin{array}{l}\text { Anak dapat mengatur peralatan belajarnya dengan } \\
\text { rapi secara mandiri }\end{array}$ \\
\hline 4 & $\begin{array}{l}\text { Menjawab pertanyaan } \\
\text { terkait video "Gloria Anak Mandiri” yang diputar di } \\
\text { kelas }\end{array}$ \\
\hline 5 & $\begin{array}{l}\text { Menyanyikan lagu “Aku } \\
\text { Mandiri” }\end{array}$ \\
\hline
\end{tabular}

Hasil observasi pertama yang dilakukan peneliti terhadap 20 anak usia dini kelompok TK B 
terkait pembelajaran di kelas di peroleh data sebagai berikut.

Grafik 1 Hasil Pengamatan Sebelum Melihat Video Pembelajaran

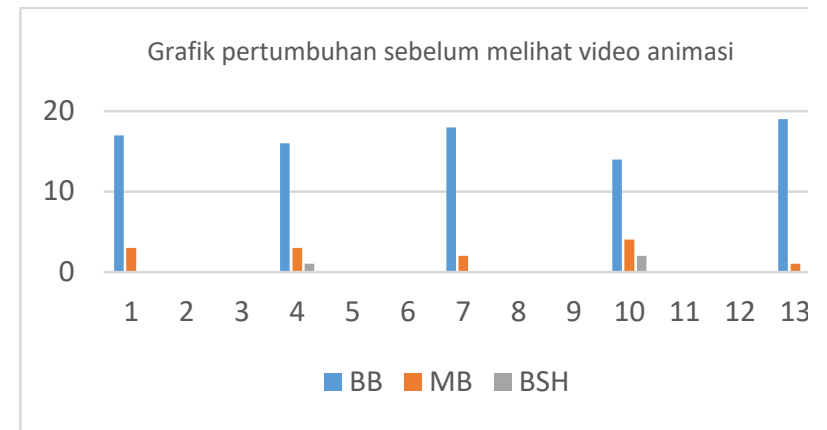

Setelah peneliti melakukan observasi pertama diperoleh hasil bahwa banyak anak yang BB (Belum Berkembang) terkait perilaku yang mencerminkan karakter mandiri. Kemudian peneliti menerapkan strategi cooperative learning dalam pembelajaran tema kebutuhanku, sub tema kebersihan dengan menggunakan media video animasi pembelajaran. Anak juga diarahkan mengisi angket (dengan pendampingan dari guru kelas) terkait video animasi pembelajaran, untuk mengetahui efektivitas media tersebut. Dari hasil uji coba media tersebut diperoleh data bahwa media sangat layak di gunakan dan bias dilanjutkan untuk pembelajaran yang relevan.

Hari kelima uji coba penerapan strategi cooperative learning dan penggunaan media video animasi pembelajaran, maka peneliti mendapatkan data sebagai berikut:

Grafik 2 Hasil Pengamatan Setelah melihat Video

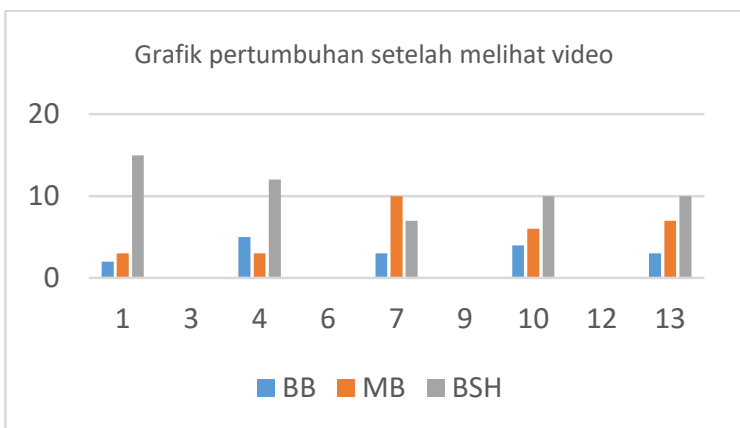

Berdasarkan grafik 2 diperoleh data bahwa ada perubahan sikap dari BB (Belum Berkembang) berubah menjadi BSH (Berkembang Sesuai Harapan) setelah penerapan strategi cooperative learning dan penggunaan media video animasi pembelajaran dalam pembelajaran nilai karakter mandiri dalam tema kebutuhanku, sub tema kebersihan..

\section{PENUTUP}

Produk media video animasi pembelajaran terintegrasi karakter mandiri untuk PAUD pada tema kebutuhanku, sub tema kebersihan yang dikembangkan untuk meningkatkan motivasi belajar dan karakter mandiri anak usia dini dinyatakan layak digunakan dalam pembelajaran menurut ahli materi dan menurut ahli media dengan nilai sangat baik. Dengan demikian, pembelajaran dengan menggunakan strategi cooperative learning dan media video animasi lebih efektif dibandingkan dengan strategi pembelajaran tradisional dan pembelajaran menggunakan media gambar dalam meningkatkan motivasi belajar siswa. Produk media video animasi pembelajaran terintegrasi karakter mandiri pada tema kebutuhanku, sub tema kebersihan efektif untuk meningkatkan karakter mandiri anak usia dini PAUD Permata Tambrauw. Hal ini terlihat dari hasil uji kelompok kecil dan uji lapangan dengan presentase 95 dan $94 \%$ yaitu layak dan valid. Dengan demikian, pembelajaran dengan menggunakan media video animasi lebih efektif dibandingkan dengan pembelajaran menggunakan media gambar dalam meningkatkan karakter mandiri anak.

\section{DAFTAR PUSTAKA}

Astuti, Y. \& Mustadi, A. 2014. Pengaruh Penggunaan Media Film Animasi terhadap Keterampilan Menulis Karangan Narasi Siswa Kelas V SD. Jurnal

Barak, M., Ashkar, T., \& Dori Y.J. 2011. Learning Science Via Animated Movies: It's Effect on Students' Learning Outcomes and Motivation. Computers \& Education Journal, Vol. 56(4), pp. 839846.

Branch, Robert Maribe. 2009. Instructional Design: The ADDIE Approach. New York: Springer.

Gagne, R.M. \& Briggs, L.J. 1979. Principles of Instructional Design (2nd Ed.). New York: Holt, Rinehart, and Winston.

Harisson, H.L. \& Hummel, L.J. 2010. "Incorporating Animation Concept and Principles in STEM Education". Journal the Technology Teacher, pp. 20-25.

Ivers, K.S. \& Baron, A.E. 2010. Multimedia Projects Ineducation Designing Producing and Assesing (4th ed). Santa Barbara: Abc. Clio. Llc. 
38 JINOTEP (Jurnal Inovasi dan Teknologi Pembelajaran): Kajian dan Riset dalam Teknologi Pembelajaran Vol. 6, No. 1, Oktober 2019, Hal 30-38

Kayaoglu, M.N., Akbas, D. \& Ozturk, Z. 2011. A Small Scale Experimental Study: Using Animations to Learn Vocabulary. The Turkey Online Journal on Educational Technology, Vol. 10(2), pp. $1-8$.

Kementerian Pendidikan Nasional. 2011. Panduan Pelaksanaan Pendidikan Karakter. Jakarta: Puskur.

Kemp. J.E. \& Dayton, D.K. 1985. Planning and Producing Instructional Media (5th Ed.). New York: Harper\& Row.

Maunah, Binti. 2015. Implementasi Pendidikan Karakter dalam Pembentukan Kepribadian Holistik Siswa. http://id.portalgaruda.org/?ref=browse\&mod=view $\underline{\text { article } \& \text { article }=416565}$

Menteri Pendidikan dan Kebudayaan. 2006. Permendikbud Nomor 22 Tahun 2006 Tentang Standar Isi untuk Satuan Pendidikan Dasar dan Menengah.

Muslimin, I., Muhammad. 2017. Pengaruh Penggunaan Video Animasi terhadap Hasil Belajar Pendidikan Kewarganegaraan Kelas II SD. Journal. student.uny.ac.id/ojs/index.php/fiptp/article/downloa $\mathrm{d} / 6106 / 5823$.

Prasetyo, Bismo. 2018. Pengembangan Media Video Animasi Untuk Pembelajaran Memproduksi Teks Hasil Laporan Observasi. https://journal.unnes.ac.id/sju/index.php/ipbsi/arti cle/view/12727

Smaldino, L., Lowther, D. L. \&Russel, J. D. 2012. Instructional Technology and Media for Learning (10th ed). (Terjemahan Arif Rahman). Boston: Pearson. (Buku Asli Diterbitkan Tahun 2012).

Undang-Undang Nomor 20 Tahun 2003 tentang Sistem Pendidikan Nasional.

Wahyuono, Hendraeka. 2017. Pengembangan Media Video Animasi pada Pembelajaran Tematik Tema Lingkungan Kelas III SDN Lowokwaru I Malang. http://eprints.umm.ac.id/35492/

Widoyoko, E.P. 2011. Evaluasi Program Pembelajaran Panduan Praktis bagi Pendidik dan Calon Pendidik. Yogyakarta: Pustaka Pelajar.

Widiastuti. 2016. Pengembangan Multimedia Lectora pada Pembelajaran Tematik Integratif Berbasis Character Building bagi Siswa Kelas IV SD. http://id.portalgaruda.org/?ref=browse\&mod=view article\&article $=416567$
Widiyasanti, Margareta. 2018. Pengembangan Media Video Animasi untuk Meningkatkan Motivasi Belajar dan Karakter Tanggung Jawab Siswa Kelas V.

https://journal.uny.ac.id/index.php/jpka/article/view/ $\underline{21489 / 11390}$

Zahroh, F. 2014. The Implementation of Animated Film as Media to Teach Writing Narrative Text to the Eighth Grade Students of Junior High School. Journal State University of Surabaya. Vol. 2 